\title{
Viewpoint \\ Mutations in DNA damage response genes and breast cancer susceptibility
}

\author{
Robert B. Clarke
}

Breast Biology Group, Clinical Research Department, Christie Hospital NHS Trust, Wilmslow Road, Manchester

Published: 4 October 2002

The risk of breast cancer is greatly increased in women who carry a mutation in one of the breast cancer susceptibility genes $B R C A 1$ or 2 . In the years since these genes were first isolated, evidence of their function in DNA damage responses and the DNA repair mechanism has accumulated. The DNA damage resulting from ionising and UV irradiation activates the ataxia-telangiectasiamutated (ATM) and ataxia-telangiectasia- and RAD3related (ATR) protein kinases, which in turn leads to the phosphorylation of BRCA proteins and other downstream targets such as CHEK2. It is known that the BRCA1 and 2 and CHEK2 gene products are cellular proteins that function to sense DNA damage, and to activate genes that both prevent cell cycle progression and initiate the DNA repair process. Several articles published over the last year have broadened our understanding of this pathway and its relevance to breast cancer risk and development.

$B R C A 1$ and 2 mutations in women at increased risk of cancer are often predicted to lead to truncated proteins lacking the C-terminal region. Recently, the crystal structure of the functionally important BRCA 1 C-terminal (BRCT) repeat region has been resolved by Williams and colleagues (Nat Struct Biol 2001, 8:838-842). The data demonstrate that BRCT repeats within the protein are similar in structure, and pack together in a head to tail alignment. Interestingly, BRCA1 missense mutations that increase susceptibility to breast cancer cluster at the predicted interface between these repeats and destabilise the structure. This supports the functional importance of the BRCT repeat domain in cellular responses to DNA damage and breast cancer susceptibility. Another report by Chiba and Parvin has identified 4 distinct, multi-protein, BRCA1-containing, cellular complexes ( $\mathrm{J} \mathrm{Biol}$ Chem 2001, 276:38549-38554). These include a complex with RAD50 (a molecule known to be involved in DNA damage response), a complex containing RNA Polymerase II, and a previously uncharacterised complex that forms in response to DNA replication inhibition, and contains the
Breast Cancer Res 2002, 4:253-254 (DOI 10.1186/bcr549)

(C) 2002 BioMed Central Ltd

(Print ISSN 1465-5411; Online ISSN 1465-542X)

BRCA1-associated RING domain protein BARD1. Evidence continues to emerge of other links between DNA damage response genes, such as BRCA1, and DNA repair (for example, see article by Hartman and Ford, Nat Genet 2002, 32:180-184). BRCA1 can, it turns out, trigger global genome repair independently of p53, and also induce expression of the nucleotide excision repair genes XPC, DDB2 and GADD45.

The search for gene mutations that explain why nonBRCA1/2 families can have high breast cancer penetrance has shown that other known proteins of the DNA damage response pathway are involved. Two papers report preliminary studies which showed that specific missense but not truncating mutations of the ATM gene have dominant negative effects on ATM function and segregate with breast cancer cases in some non-BRCA1/2 families with multiple cases of breast cancer (see Chenevix-Trench et al., J Natl Cancer Inst 2002 94:205-215 and Scott et al., Proc Natl Acad Sci 2002 99:925-930). Two other reports demonstrate that $1100 \mathrm{delC}$, a specific CHEK2 truncating mutation, confers low penetrance susceptibility to breast cancer (see Meijers-Heijboer et al., Nat Genet 2002 31:55-59 and Vahteristo et al., Am J Hum Genet 2002 71:432-438). The evidence indicates that the 1100 delC mutation contributes to familial clustering of breast cancer cases and, in particular, increases the rates of male breast cancer.

Finally, in a landmark publication earlier this year in Nature, van 't Veer and colleagues from the Netherlands Cancer Institute and Rosetta Inpharmatics suggested that breast cancer recurrence could be predicted by a gene expression signature involving as few as 70 genes (Nature 2002, 415:530-536). The authors also analysed a group of tumours from germ-line BRCA1 mutation carriers and established a molecular signature of 100 genes whose expression levels identifies this group as a distinct subset of breast cancers. 
These articles increase our knowledge of which genes function up- or down-stream of BRCA proteins and how mutations in these genes confer breast cancer susceptibility. This improved understanding may help us find novel strategies to prevent breast cancer through recognising those at risk. In addition, the finding that BRCA1 tumours have a specific molecular signature suggests that breast cancers caused by different germ-line gene mutations comprise separate subsets of tumours that can be targeted by specific therapies.

\section{Articles selected from Faculty of $\mathbf{1 0 0 0}$}

Chenevix-Trench G, Spurdle AB, Gatei M, Kelly H, Marsh A, Chen X, Donn K, Cummings M, Nyholt D, Jenkins MA, Scott C, Pupo GM, Dörk T, Bendix R, Kirk J, Tucker K, McCredie MR, Hopper JL, Sambrook J, Mann GJ, Khanna KK: Dominant negative ATM mutations in breast cancer families. J Natl Cancer Inst 2002, 94:205-215.

Chiba N, Parvin JD: Redistribution of BRCA1 among four different protein complexes following replication blockage. J Biol Chem 2001, 276:38549-38554.

Hartman AR, Ford JM: BRCA1 induces DNA damage recognition factors and enhances nucleotide excision repair. Nat Genet 2002, 32:180-184.

Meijers-Heijboer $\mathrm{H}$, van den Ouweland A, Klijn J, Wasielewski M, de Snoo A, Oldenburg R, Hollestelle A, Houben M, Crepin E, van Veghel-Plandsoen M, Elstrodt F, van Duijn C, Bartels C, Meijers C, Schutte M, McGuffog L, Thompson D, Easton D, Sodha N, Seal S, Barfoot R, Mangion J, Chang-Claude J, Eccles D, Eeles R, Evans DG, Houlston R, Murday V, Narod S, Peretz T, Peto J, Phelan C, Zhang HX, Szabo C, Devilee P, Goldgar D, Futreal PA, Nathanson KL, Weber B, Rahman N, Stratton MR: Low-penetrance susceptibility to breast cancer due to CHEK2(*)1100delC in noncarriers of BRCA1 or BRCA2 mutations. Nat Genet 2002, 31:55-59.

Scott SP, Bendix R, Chen P, Clark R, Dork T, Lavin MF: Missense mutations but not allelic variants alter the function of ATM by dominant interference in patients with breast cancer. Proc Natl Acad Sci U S A 2002, 99:925-930.

Vahteristo P, Bartkova J, Eerola H, Syrjakoski K, Ojala S, Kilpivaara O, Tamminen A, Kononen J, Aittomaki K, Heikkila P, Holli K, Blomqvist C, Bartek J, Kallioniemi OP, Nevanlinna H: A CHEK2 genetic variant contributing to a substantial fraction of familial breast cancer. Am J Hum Genet 2002, 71:432-438.

van 't Veer LJ, Dai $H$, van de Vijver MJ, He YD, Hart AA, Mao M, Peterse HL, van der Kooy K, Marton MJ, Witteveen AT, Schreiber GJ, Kerkhoven RM, Roberts C, Linsley PS, Bernards R, Friend $\mathrm{SH}$ : Gene expression profiling predicts clinical outcome of breast cancer. Nature 2002, 415:530-536.

Williams RS, Green R, Glover JN: Crystal structure of the BRCT repeat region from the breast cancer-associated protein BRCA1. Nat Struct Biol 2001, 8:838-842. 